Gut, 1983, 24, 99-105

\title{
T lymphocyte subsets in inflammatory bowel disease: peripheral blood
}

\author{
W S SELBY AND D P JEWELL \\ From the Department of Gastroenterology, John Radcliffe Hospital, Headington, Oxford
}

SUMmary Peripheral blood T lymphocytes and T lymphocyte subsets have been quantified in 28 patients with ulcerative colitis and 26 with Crohn's disease by an indirect immunofluorescence technique using monoclonal antibodies: OKT3, which detects all peripheral blood $\mathrm{T}$ lymphocytes; OKT4 (T cells of helper phenotype); and OKT8 (T cells of supressor-cytotoxic phenotype). Eighteen normal subjects and 16 patients with a variety of non-inflammatory gastrointestinal disorders were studied as controls. No significant differences were found between patient and control groups in the proportions of circulating T lymphocytes or their subsets. When compared with normal subjects, absolute numbers of $\mathrm{T}$ lymphocytes were reduced in patients with active ulcerative colitis or Crohn's disease $(\mathrm{p}<0 \cdot 05) . \mathrm{OKT}^{+} \mathrm{T}$ cell numbers were reduced in ulcerative colitis, whether active $(p<0.02)$ or inactive $(p<0.05)$ and in active Crohn's disease $(p<0.05)$ Numbers of $\mathrm{OKT}^{+} \mathrm{T}$ cells were reduced in active Crohn's disease $(\mathrm{p}<0.01)$. There were no differences in $\mathrm{T}$ lymphocyte numbers between the patient groups and the disease control subjects. The $\mathrm{OKT} 4^{+}: \mathrm{OKT}^{+}$ratio in patients with inflammatory bowel disease did not differ from that in controls. No relation was found between any of the parameters studied and disease activity, site, or extent of disease, or treatment with sulphasalazine or corticosteroids. The presence of Ia-like, HLA-DR antigens on $\mathrm{T}$ cells was detected using a double marker immunofluorescence technique. In control subjects up to $7 \%$ of $\mathrm{OKT}^{+}$cells were HLA-DR ${ }^{+}$.


results indicate that the pathogenesis of ulcerative colitis or Crohn's disease does not depend upon an alteration in the proportion of circulating $\mathrm{T}$ lymphocytes nor upon an imbalance of $\mathrm{T}$ lymphocyte subsets as defined by monoclonal antibodies. The reduction in $T$ lymphocyte numbers may result from mucosal infiltration. The findings also suggest that circulating $\mathrm{T}$ lymphocytes are not activated.

The pathogenesis of inflammatory bowel disease (ulcerative colitis and Crohn's disease) is unknown. Immunological mechanisms, however, both humoral and cell-mediated, may be involved. ${ }^{1}$ There is also evidence of impairment of some aspects of cell-mediated immunity. ${ }^{2-6}$ In particular, defective suppressor cell function has been found in the peripheral blood of patients with inflammatory bowel disease using a variety of assay systems. ${ }^{7-10}$ Studies of the proportion and number of total circulating $T$ lymphocytes, using sheep red cell rosetting techniques, have yielded conflicting results. ${ }^{11-17}$ The proportion of $T$ cells in the

Received for publication 17 May 1982 peripheral blood bearing an Fc-receptor for IgM $(\mathrm{T} \mu)$ is reduced in patients with Crohn's disease, while conflicting results have been obtained for $\mathrm{T}$ cells with an Fc-receptor for IgG (T $\gamma) .^{1018} 19$ These subsets were originally thought to represent the helper and suppressor subsets of $\mathrm{T}$ lymphocytes, respectively, ${ }^{20}$ but this no longer seems to be true. ${ }^{21}$ The development of a panel of monoclonal antibodies which detect total $T$ lymphocytes, as well as the helper $\mathrm{T}$ cell and the suppressor-cytotoxic $\mathrm{T}$ cell subsets has enabled study of these cell populations in the peripheral blood of patients with a variety of diseases. ${ }^{22}$

The aim of the present study was to examine the proportions and numbers of $\mathrm{T}$ lymphocytes and 
their subsets in the peripheral blood of patients with inflammatory bowel disease using an indirect immunofluoresence technique, to determine if an imbalance of immunoregulatory $\mathrm{T}$ cells is important in the pathogenesis of inflammatory bowel disease. In addition, activated $T$ lymphocytes have been detected using an anti-serum to HLA-DR antigens in a double marker immunofluorescence assay.

\section{Methods}

\section{SUBJECTS}

Twenty-eight patients with ulcerative colitis and 26 with Crohn's disease were studied. The diagnosis of ulcerative colitis or Crohn's disease was based on characteristic clinical, endoscopic, histological, and radiological features. The extent of disease was determined by radiological and/or colonoscopic findings. The mean age of the 28 patients with ulcerative colitis (14 men, 14 women) was 45 years (range: 16-91 years). In three, disease was limited to the rectum, 13 had left-sided colonic involvement, four disease to and including the transverse colon, and eight had universal colitis. Activity was assessed by the method of Truelove and Witts. ${ }^{23}$ The colitis was active in 18 patients (eight mild; five moderate; five severe) and inactive in 10 . Eighteen patients were receiving sulphasalazine $(2 \mathrm{~g} /$ day $)$ and five were also taking oral prednisolone $(2 \cdot 5-20 \mathrm{mg} /$ day $)$. Of the 26 patients with Crohn's disease ( 9 men, 17 women) the mean age was 39 years (range: 16-66 years). Seven patients had disease confined to the ileum, 12 to the colon, and seven had ileocolonic involvement. The criteria of DeDombal et al were used to determine disease activity. ${ }^{24}$ Fourteen patients had active disease (six mild; three moderate; five severe), while in 12 disease was quiescent. Sixteen patients were taking sulphasalazine ( $2 \mathrm{~g} /$ day), eight were taking prednisolone (5-50 mg/day), and three were receiving azathioprine (100-150 mg/day).

Two groups of control subjects were studied: (1) 18 healthy subjects $(10$ men, 8 women) with a mean age of 34 years (range: $21-65$ years); (2) 16 patients with a variety of non-inflammatory gastrointestinal disorders (four with irritable colon syndrome, two with iron deficiency and one with folate deficiency, two with gastrointestinal malignancy, two with colonic polyps, two with hypolactasia, and one each with ischaemic colitis, radiation proctitis, and Hirschprung's disease). The mean age of these patients was 47 years (range: $15-70$ years).

\section{ANTIBODIES}

The OKT series of monoclonal antibodies (Ortholabs, New Jersey) was used to detect $\mathrm{T}$ lymphocytes and their subsets. ${ }^{22}$ OKT3 reacts with all peripheral blood $\mathrm{T}$ cells as well as with mature thymocytes. OKT4 reacts with $\mathrm{T}$ cells of helper phenotype. These cells are capable of responding to soluble antigens, of helping the differentiation of B cells and of providing help for cytotoxic $T$ cells. OKT8 detects $T$ cells of suppressor-cytotoxic phenotype. These cells do not respond to soluble antigens in vitro but do respond to alloantigens and non-specific mitogens. They can suppress $T$ and $B$ cell functions and are capable of cytotoxicity after activation by mixed lymphocyte culture. In an indirect immunofluorescence technique goat antimouse antiserum conjugated with fluorescein isothiocyanate (Nordic; GAM FITC) was used as a second layer. HLA-DR, Ia-like antigens were detected using an antiserum raised in chickens. ${ }^{25}$ These antigens are found on B cells, monocytes, and on some tissue macrophages including those of the intestinal lamina propria. ${ }^{25}$ Their presence on a small population of peripheral blood $T$ cells has been associated with activation of these cells. ${ }^{26}{ }^{27} \mathrm{~A}$ rabbit anti-chicken antiserum conjugated with tetramethylrhodamine isothiocyanate (Miles; RAC TRITC) was used as a second layer.

\section{PERIPHERAL BLOOD MONONUCLEAR CELLS AND IMMUNOFLUORESCENCE}

Peripheral blood mononuclear cells were isolated from heparinised venous blood by centrifugation on a Ficoll-hypaque density gradient (Pharmacia, Sweden). ${ }^{28}$ After washing, $1 \times 10^{6}$ cells in $50 \mu \mathrm{l}$ of phosphate buffered saline containing $0.1 \%$ sodium azide were incubated with the appropriate monoclonal antibody (at 1:25 dilution) and with the antiserum to Ia-like antigens (1:10). After incubation for 10 minutes at room temperature the cells were washed twice and resuspended in $50 \mu \mathrm{l}$ phosphate buffered saline and azide. They were then incubated with GAM FITC (1:25) and RAC TRITC (1:10) and subsequently washed and mounted on glass slides with a drop of $90 \%$ glycerol in phosphate buffered saline. Negative immunofluorescence controls were performed using a monoclonal antibody which reacts only with cortical thymocytes but not with peripheral blood lymphocytes (NA1/34) ${ }^{29}$ and also using normal chicken serum in place of the first layer antibodies.

\section{FLUORESCENCE MICROSCOPY AND}

QUANTIFICATION

The proportion of lymphocytes exhibiting immunofluorescence was counted using a Zeiss Universal fluorescence microscope with epiillumination. Selective filters for fluorescein and rhodamine enabled the simultaneous detection of $\mathrm{T}$ 
cell and Ia-like antigens on individual cells. At least 200 lymphocytes were counted for each antibody. Monocytes were excluded by their morphology and membrane-associated HLA-DR antigens. The absolute number of lymphocytes was determined from the white cell count, performed on a Coulter counter, and from the white cell differential analysis of Wright-stained smears.

\section{STATISTICAL ANALYSIS}

The results in each of the patient groups were compared with those in each of the control groups using Student's $t$ test. Results are expressed as mean \pm SEM.

\section{Results}

The proportion of lymphocytes in the peripheral blood of patients with inflammatory bowel disease was significantly lower than normal (Table 1). This was true for patients with active ulcerative colitis $(p<0.01)$ and for those with Crohn's disease, whether active $(p<0.01)$ or inactive $(p<0.05)$. In the disease control subjects the proportion of lymphocytes was also lower than normal $(p<0 \cdot 05)$. There was no difference in the proportion of OKT3-positive, OKT4-positive, or OKT8-positive T cells between any of the patient groups and the normal or disease control subjects.

The total white cell count in patients with inflammatory bowel disease tended to be higher than in the control subjects (Table 2). Because of the reduced proportion of lymphocytes, however, the absolute numbers of lymphocytes also tended to be lower than normal in the patients with inflammatory bowel disease, although the difference reached statistical significance only in patients with active Crohn's disease $(p<0.02)$. The number of $\mathrm{OKT}^{+}$lymphocytes was reduced in comparison with normal subjects in patients with active ulcerative colitis $(\mathrm{p}<0.05)$ or active Crohn's disease $(p<0.05)$. The number of circulating $\mathrm{OKT}_{4}{ }^{+}$cells was also significantly below normal in these patients, and also in patients with ulcerative colitis in remission $(p<0.05)$. The reduction in the number of OKT ${ }^{+}$lymphocytes differed from normal only in patients with active Crohn's disease $(p<0 \cdot 001)$.

When the findings in patients with inflammatory bowel disease were compared with those in the disease control group no significant differences were found for any of the parameters studied.

The ratio of $\mathrm{OKT}_{4}^{+}$to $\mathrm{OKT}^{+} \mathrm{T}$ cells is considered important in the analysis of disorders of immunoregulation. No significant difference in the ratio was found between the control subjects and the patients with ulcerative colitis or Crohn's disease (Fig. 1). Although in several patients the ratio fell outside the normal range, there were no clinical or other features to suggest that these patients constituted a particular subgroup.

There was no relation between any of the parameters studied and disease activity, site, extent, or mode of treatment.

HLA-DR antigens were detected on circulating T lymphocytes in nine of 16 normal subjects and 11 of 16 disease controls, with up to $7 \%$ of $\mathrm{OKT}^{+}$cells being HLA-DR ${ }^{+}$(Fig. 2). Although more patients with inflammatory bowel disease had HLA-DR ${ }^{+} \mathrm{T}$ cells, in only three was the proportion higher than in the controls (two with active ulcerative colitis and one with active Crohn's disease). The proportion of HLA-DR ${ }^{+} \mathrm{T}$ cells was not related to the severity or site of disease, nor to the form of treatment being received. Both $\mathrm{OKT}^{+}{ }^{+} \mathrm{HLA}^{-\mathrm{DR}^{+}}$and $\mathrm{OKT} 8^{+}$ HLA-DR ${ }^{+}$cells were found.

found.

\section{Discussion}

Studies of circulating $\mathrm{T}$ lymphocyte numbers using sheep red cell rosetting techniques in patients with inflammatory bowel disease have yielded conflicting results. In ulcerative colitis, $T$ cell proportions may be normal ${ }^{1214}{ }^{17}$ or reduced. ${ }^{3513}$ Similar

Table 1 Proportions of lymphocytes and T lymphocyte subpopulations in peripheral blood of patients with ulcerative colitis or Crohn's disease and in controls.

\begin{tabular}{|c|c|c|c|c|c|c|}
\hline & \multirow[b]{2}{*}{ Normal } & \multirow{2}{*}{$\begin{array}{l}\text { Disease } \\
\text { control }\end{array}$} & \multicolumn{2}{|c|}{ Ulcerative colitis } & \multicolumn{2}{|c|}{ Crohn's disease } \\
\hline & & & Active & Inactive & Active & Inactive \\
\hline Lymphocytes ( $\%$ ) & $33 \pm 2$ & $26 \pm 2^{*}$ & $24 \pm 2 \div$ & $30 \pm 3$ & $21 \pm 3+$ & $26 \pm 3^{*}$ \\
\hline $\mathrm{OKT}^{-}(\%)$ & $70 \pm 1$ & $69 \pm 2$ & $66 \pm 2$ & $70 \pm 2$ & $70 \pm 2$ & $69 \pm 3$ \\
\hline $\mathrm{OKT}^{+}(\%)$ & $49 \pm 1$ & $48 \pm 2$ & $43 \pm 3$ & $48 \pm 3$ & $48 \pm 3$ & $49 \pm 2$ \\
\hline $\mathrm{OKT}^{+}(\%)$ & $21 \pm 1$ & $17 \pm 2$ & $22 \pm 2$ & $21 \pm 3$ & $18 \pm 2$ & $18 \pm 2$ \\
\hline
\end{tabular}

${ }^{*} \mathrm{p}<0.05, \div \mathrm{p}<0.01$

Results expressed as mean \pm SEM. Values of $p$ represent comparisons with the results of normal subjects. 
Table 2 Numbers of white blood cells (WBC), lymphocytes and T lymphocytes in peripheral blood of patients with ulcerative colitis or Crohn's disease and in controls

\begin{tabular}{|c|c|c|c|c|c|c|}
\hline & \multirow[b]{2}{*}{ Normal } & \multirow{2}{*}{$\begin{array}{l}\text { Disease } \\
\text { Control }\end{array}$} & \multicolumn{2}{|c|}{ Ulcerative Colitis } & \multicolumn{2}{|c|}{ Crohn's disease } \\
\hline & & & Active & Inactive & Active & Inactive \\
\hline $\mathrm{WBC}^{*}$ & $7 \cdot 2 \pm 0 \cdot 5$ & $7 \cdot 2 \pm 0 \cdot 5$ & $8 \cdot 1 \pm 0 \cdot 5$ & $6 \cdot 2 \pm 0 \cdot 3$ & $8.4 \pm 0.7$ & $7 \cdot 7 \pm 0.6$ \\
\hline Lymphocytes & $2 \cdot 33 \pm 0 \cdot 17$ & $1 \cdot 88 \pm 0 \cdot 23$ & $1 \cdot 90 \pm 0 \cdot 16$ & $1 \cdot 83 \pm 0 \cdot 17$ & $1.67 \pm(0) \cdot 18 \ddagger$ & $1.99 \pm 0.23$ \\
\hline $\mathrm{OKT}^{+}$ & $1 \cdot 66 \pm 0 \cdot 14$ & $1 \cdot 30 \pm 0 \cdot 16$ & $1 \cdot 26 \pm 0 \cdot 11 \div$ & $1 \cdot 27 \pm 0 \cdot 11$ & $1 \cdot 22 \pm 0 \cdot 14 \dagger$ & $1 \cdot 40 \pm(0 \cdot 19$ \\
\hline $\mathrm{OKT}^{+}$ & $1 \cdot 15 \pm 0.09$ & $0.91 \pm 0.13$ & $0.82 \pm 0.08 \ddagger$ & $0.85 \pm 0.06{ }^{\dagger}$ & $0.83 \pm(0.12+$ & $0.99 \pm 0.13$ \\
\hline $\mathrm{OKT}^{+}$ & $0.47 \pm 0.04$ & $0.35 \pm 0.06$ & $0.42 \pm 0.05$ & $(0 \cdot 42 \pm 0 \cdot 10$ & $0 \cdot 30 \pm(0 \cdot 04 \$$ & $0.35 \pm 0.05$ \\
\hline
\end{tabular}

$* \times 10^{4} / 1,+\mathrm{p}<0.05, \ddagger \mathrm{p}<0.02, \S \mathrm{p}<0.01$

Results expressed as mean \pm SEM. Values of p represent comparisons with the results of normal controls.

variation has been found in patients with Crohn's disease. ${ }^{3}{ }^{11-17}$ These varying results have been attributed to a number of factors, including duration of disease ${ }^{16}$ mode of treatment ${ }^{5} 15$ and state of nutrition. ${ }^{11}$ The rosetting method used is also important. ${ }^{30}$ In particular, the ratio of sheep red blood cells to lymphocytes used in the assay can influence results. ${ }^{17}$ Dopp et al have shown a reduction in circulating 'avid' rosetting cells (low sheep red blood cells: lymphocyte ratio) in patients with ulcerative colitis or Crohn's disease. ${ }^{17}$ This reduction was reversible with the thymic extract thymopoietin. As fetal calf serum contains a thymosin-like factor, the use of fetal calf serum may also influence the number of rosetting cells. The considerable variation in proportions of rosetting

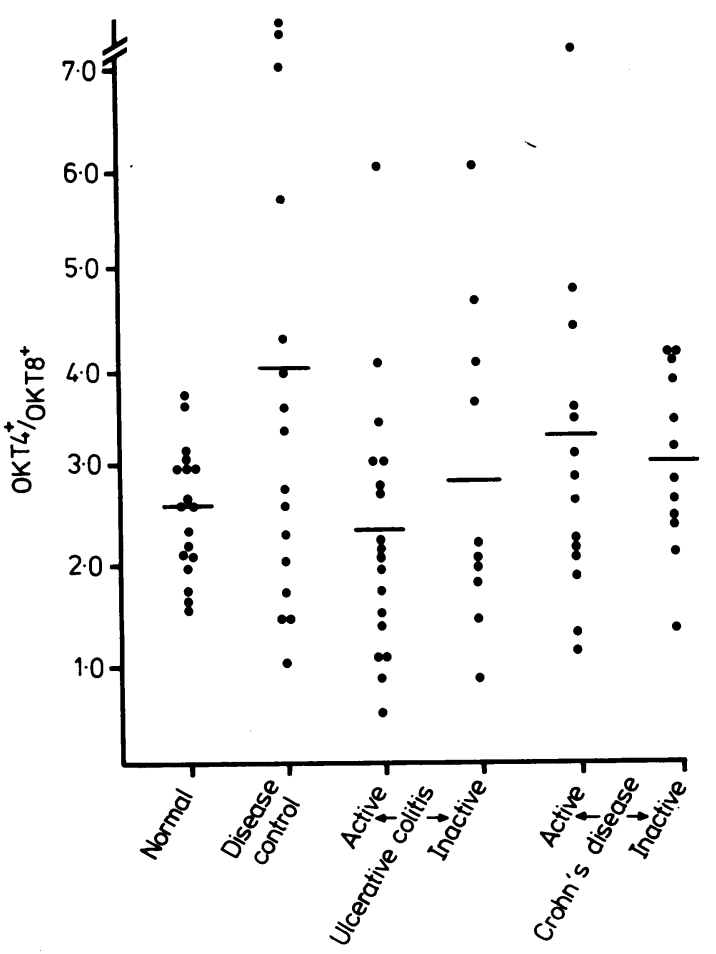

Fig. 1 Ratio of the proportions of $\mathrm{OKT4}^{+}$to $\mathrm{OKT8^{+ }} \mathrm{T}$ lymphocytes in the peripheral blood of patients and control subjects. Bar represents the mean value.

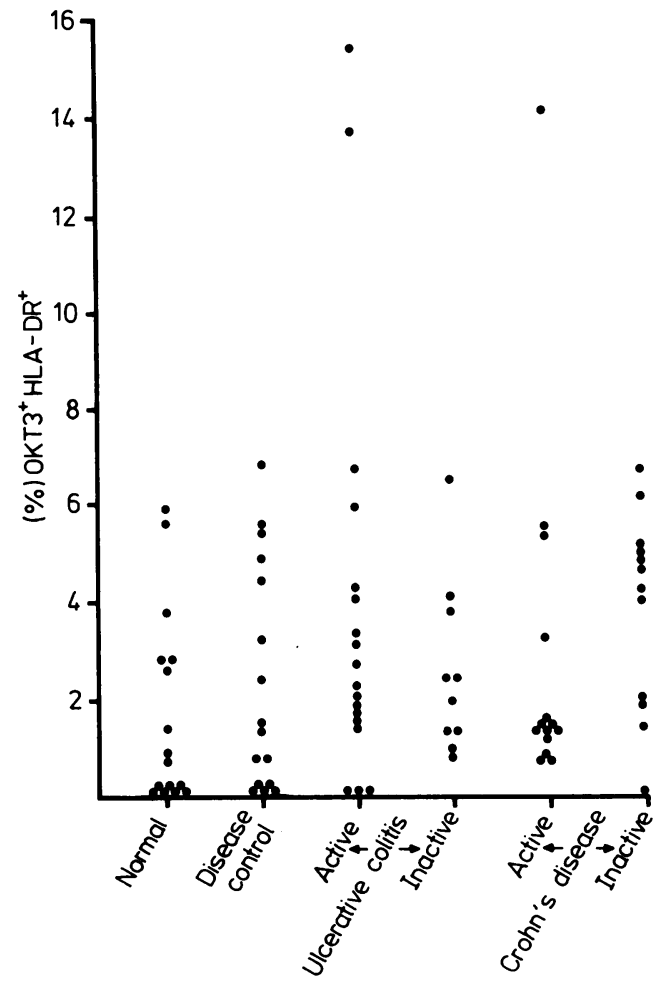

Fig. 2 Proportion of circulating $\mathrm{OKT3}^{+} \mathrm{T}$ lymphocytes expressing $H L A-D R$ antigens in patients and control subjects. 
cells found in normal subjects in the above reports confirms that the method used for rosette formation may indeed have contributed to the conflicting results. In the only study to examine $\mathrm{T}$ lymphocyte numbers using a conventional anti-human thymocyte antiserum, Strickland et $a l^{12}$ found a normal proportion of $T$ cells in the circulation of patients with ulcerative colitis but a reduced percentage in patients with Crohn's disease. The antiserum detected more cells than did sheep red blood cell rosettes, and the results of the two methods for detecting $T$ cells were not always concordant. Using a monoclonal antibody which detects peripheral blood $\mathrm{T}$ lymphocytes, we have found that the proportion of these cells is normal in the peripheral blood of patients with ulcerative colitis or Crohn's disease. This was true regardless of disease activity, site, extent, or mode of treatment. The absolute number of $T$ lymphocytes was reduced in active disease, but returned to normal when the disease was quiescent. This reduction, and that of numbers of the circulating $\mathrm{T}$ lymphocyte subsets, was not specific for patients with inflammatory bowel disease, being found also in patients with non-inflammatory gastrointestinal disorders.

The presence in patients with inflammatory bowel disease especially Crohn's disease, of hyporesponsiveness to skin testing ${ }^{34}$ and lymphocyte hyporeactivity to mitogens ${ }^{25}$ or in mixed lymphocyte reaction, ${ }^{46}$ suggests that cellular immunity is impaired. The reduced numbers of circulating $T$ lymphocytes in active disease could explain, at least in part, this impairment. Previous workers have, however, been unable to correlate impaired immune function with the numbers of $T$ cells as determined by sheep red blood cell rosettes. ${ }^{3} 183132$ The significance of the thymosin-sensitive reduction of 'avid' rosetting cells described by Dopp et al is unknown. ${ }^{17}$

T lymphocytes represent a heterogeneous population of cells which are important in immune function. In particular, helper $\mathrm{T}$ cells and suppressor $T$ cells play a vital role in immune regulation. ${ }^{22}$ It is possible that imbalance between the subsets of $T$ lymphocytes may help to explain the functional abnormalities found in patients with inflammatory bowel disease, and be important in the pathogenesis of these diseases. Identification of $\mathrm{T}$ lymphocyte subsets by cell-surface markers has received considerable attention. $\mathrm{T} \mu$ and $\mathrm{T} \gamma$ cells have been identified in the circulation by the presence on their surfaces of receptors for the Fc-portion of IgM or IgG respectively. ${ }^{20} \mathrm{~T} \mu$ cells were thought to represent predominantly the helper subset of $T$ lymphocytes, and $\mathrm{T} \gamma$ the suppressor subset. The proportion of $T \mu$ cells is reduced in the circulation of patients with inflammatory bowel disease, independently of disease activity, ${ }^{18}{ }^{19}$ whereas the level of T $\gamma$ cells may be normal ${ }^{18}$ or reduced. ${ }^{919}$ The development of monoclonal antibodies to $T$ lymphocytes with helper function (OKT4) or suppressor-cytotoxic function (OKT8) has enabled more precise assessment of these $T$ cell subsets in the circulation. Analysis with these antibodies has revealed that the $T \mu$ subpopulation is, in fact, made up of both helper-type and suppressor-cytotoxictype $T$ cells, and is similar to the unseparated $T$ cell population. ${ }^{21}$ The $T \gamma$ population contains few $\mathrm{T}$ lymphocytes, and consists largely of lymphocytes bearing a monocyte marker (? natural killer cells). Thus interpretation of a reduction in the proportion of circulating $\mathrm{T} \mu$ cells in inflammatory bowel disease is difficult, and may not reflect an imbalance of immunoregulatory $T$ cells. The present study indicates that the proportions of $\mathrm{T}$ cells of helper phenotype $\left(\mathrm{OKT}_{4}^{+}\right)$and of $\mathrm{T}$ cells of suppressorcytotoxic phenotype $\left(\mathrm{OKT}^{+}\right)$are not significantly altered in either ulcerative colitis or Crohn's disease, although, in patients with ulcerative colitis, the absolute number of circulating $\mathrm{OKT} 4^{+}$lymphocytes is reduced, and in those with active Crohn's disease, both $\mathrm{OKT}_{4}^{+}$and $\mathrm{OKT}^{+}{ }^{+} \mathrm{T}$ cells are present in lower numbers than normal. Functional analysis of peripheral blood $T$ cells in patients with inflammatory bowel disease has demonstrated an impairment both of ConA-induced ${ }^{79}$ and spontaneous suppressor cell activity. ${ }^{10}$ The reduction in ConA-induced suppression is particularly marked in patients with active disease. This impairment can be explained only partly by the presence of reduced numbers of circulating $\mathrm{OKT} 8^{+}$, suppressor-cytotoxic-type cells, as these were reduced only in patients with active Crohn's disease. The present results, however, do not exclude an imbalance between suppressor and cytotoxic $T$ cells in the circulation. The development of monoclonal antibodies which can differentiate these two subsets may solve this problem.

In many patients with autoimmune disease, the ratio of $\mathrm{OKT}_{4}^{+}$to $\mathrm{OKT}^{+} \mathrm{T}$ lymphocytes is increased, reflecting a relative or absolute deficiency of suppressor-cytotoxic-type $\mathrm{T}$ cells. ${ }^{33} \mathrm{~A}$ similar increase has been found in patients with active multiple sclerosis and in patients with some forms of glomerulonephritis. ${ }^{34}$ In contrast, the ratio tends to be reduced in patients with certain infections - for example, infectious mononucleosis, cytomegalovirus, and hepatitis B infections - and in some forms of immunodeficiency. ${ }^{34}$ The normal ratio in the circulation of patients with inflammatory bowel disease is evidence against these disorders being 
primarily autoimmune or because of an immunodeficiency state. The defective suppressor cell function outlined previously is also not explained by the presence of an imbalance between $\mathrm{OKT}_{4}{ }^{+}$and $\mathrm{OKT}^{+}{ }^{+} \mathrm{T}$ lymphocytes.

The normal circulation may contain a small proportion of T lymphocytes which have membraneassociated Ia-like, HLA-DR antigens. ${ }^{26}$ This was confirmed in our study. Only three patients with inflammatory bowel disease had a higher proportion of HLA-DR-positive T lymphocytes than controls (two with active ulcerative colitis and one with active Crohn's disease). Yu et al found a similar increase in four of seven patients with inflammatory bowel disease. ${ }^{26}$ The presence of these antigens on peripheral blood $\mathrm{T}$ cells has been associated with activation, in vitro ${ }^{26} 27$ and in vivo. ${ }^{26}$ Thus the absence in the circulation of patients with inflammatory bowel disease of $\mathrm{T}$ lymphocytes expressing HLA-DR antigens suggests that circulating $T$ cells in these disorders are not activated. Using the method of stable sheep red blood cell rosettes Fiocchi et al have recently also failed to detect activated $T$ cells in the peripheral blood of patients with Crohn's disease. ${ }^{35}$

The results of this study indicate that the pathogenesis of ulcerative colitis or Crohn's disease does not depend upon an alteration in the proportion of $\mathrm{OKT}^{+}, \mathrm{T}$ lymphocytes in the peripheral blood nor on an imbalance between circulating $\mathrm{T}$ lymphocyte subsets as defined by the monoclonal antibodies OKT4 and OKT8. The findings in the peripheral blood may not, however, reflect those occurring locally. In sarcoidosis with high-intensity alveolitis the $\mathrm{OKT}_{4}^{+}: \mathrm{OKT}^{+}$ratio is reduced in the peripheral blood yet increased in pulmonary aspirates $;{ }^{36}$ in rheumatoid arthritis there is a relative deficiency of $\mathrm{OKT}^{+}$cells both in blood and in the synovial membrane. ${ }^{37}$ The reduction in $\mathrm{T}$ lymphocyte numbers found in this study may result from the mucosal $\mathrm{T}$ cell infiltration which has been demonstrated in patients with active inflammatory bowel disease. ${ }^{38}$ It is possible that within the intestinal mucosa there may be abnormal numbers or a redistribution of $\mathrm{T}$ lymphocyte subsets, or an alteration in the mucosal microenvironment which may be important in the pathogenesis of inflammatory bowel disease. A study of $T$ lymphocyte subsets in tissue sections and in mucosal mononuclear cell isolates from patients with ulcerative colitis or Crohn's disease is currently in progress.

We would like to thank $\mathrm{Dr} G$ Goldstein, Ortholaboratories, Raritan, New Jersey, USA, for the gift of the OKT series of antibodies, Dr G
Janossy, Royal Free Hospital, London, for the antiserum to HLA-DR antigens, and Mrs J Pierce, Department of Biomathematics, University of Oxford, for statistical assistance.

\section{References}

1 Thomas HC, Jewell DP. Clinical gastrointestinal immunology Oxford: Blackwell Scientific Publications: 1979: 121-63.

2 Sachar DB, Taub RN, Brown SM, Present DH, Korelitz BI, Janowitz HD. Impaired lymphocyte responsiveness in inflammatory bowel disease. Gastroenterology 1973; 64: 203-9.

3 Meyers S, Sachar DB, Taub RN, Janowitz HD. Anergy to dinitrochlorobenzene and depression of $\mathrm{T}$. lymphocytes in Crohn's disease and ulcerative colitis. Gut 1976; 17: 911-5.

4 Jones JV, Housely J, Ashurst PM, Hawkins CF. Development of delayed hypersensitivity to dinitrochlorobenzene in patients with Crohn's disease. Gut 1969; 10: 52-6.

5 Rubinstein A, Das KM, Melamed J, Murphy RA. Comparative analysis of systemic immunological parameters in ulcerative colitis and idiopathic proctitis: effects of sulfasalazine in vivo and in vitro. Clin Exp Immunol 1978; 33: 217-24.

6 Fiske SC, Falchuk ZM. Impaired mixed-lymphocyte culture reactions in patients with inflammatory bowel disease. Gastroenterology 1980; 79: 682-6.

7 Hodgson HJF, Wands JR, Isselbacher KJ. Decreased suppressor cell activity in inflammatory bowel disease. Clin Exp Immunol 1978; 32: 451-8.

8 Knapp W, Smolen JS, Lanzer G et al. Con A induced suppressor cell activity in IBD and other inflammatory diseases. In: Pena AS, Weterman IT, Booth CC, Strober W, eds. Developments in gastroenterology, volume 1. Recent advances in Crohn's disease. Martinus-Nijhoff: The Hague, 1981: 380-9.

9 Shorter RG. $T_{G}$ cells and non-specific conconavalin-Ainduced suppressor cell activity in vitro in colonic inflammatory bowel disease and in colorectal carcinoma. In: Pena AS, Weterman IT, Booth CC, Strober W, eds. Developments in gastroenterology, volume 1. Recent advances in Crohn's disease. Martinus-Nijhoff: The Hague, 1981: 448-58.

10 Victorino RMM, Hodgson HJF. Spontaneous suppressor cell function in inflammatory bowel disease. Dig Dis Sci 1981; 26: 801-6.

11 Bird AG, Britton S. No evidence for decreased lymphocyte reactivity in Crohn's disease. Gastroenterology 1974; 67: 926-32.

12 Strickland RG, Korsmeyer S, Soltis RD, Wilson ID, Williams RC Jr. Peripheral blood $\mathrm{T}$ and $\mathrm{B}$ cells in chronic inflammatory bowel disease. Gastroenterology 1974; 67: 569-77.

13 Sachar DB, Taub RN, Ramachandar K et al. T- and Blymphocytes and cutaneous anergy in inflammatory 
bowel disease. Ann NY Acad Sci 1976; 278: 565-72.

14 Thayer WR Jr, Charland C, Field CE. The subpopulations of circulating white blood cells in inflammatory bowel disease. Gastroenterology 1976; 71: $379-84$.

15 Eckhardt R, Kloos P, Dierich MP, Meyer Zum Buschenfelde KH. K-lymphocytes (killer cells) in Crohn's disease and acute virus B-hepatitis. Gut 1977; 18: 1010-16.

16 Auer I0, Wechsler W, Ziemer E, Malchow H, Sommer $H$. Immune status in Crohn's disease. I. Leukocyte and lymphocyte subpopulations in peripheral blood. Scand J Gastroenterol 1978; 13: 561-71.

17 Dopp AC, Mutchnick MG, Goldstein AL. Thymosindependent $\mathrm{T}$-lymphocyte response in inflammatory bowel disease. Gastroenterology 1980; 79: 276-82.

18 Victorino RMM, Hodgson HJF. Alteration in T lymphocyte subpopulations in inflammatory bowel disease. Clin Exp Immunol 1980; 41: 156-65.

19 Pena AS, Cnossen J, Damsteeg MG. T-cell subpopulations in Crohn's disease. In: Pena AS, Weterman IT, Booth CC, Strober W, eds. Developments in gastroenterology, volume 1. Recent advances in Crohn's disease. Martinus-Nijhoff: The Hague, 1981: 403-7.

20 Moretta L, Webb SR, Grossi CE, Lydyard PM, Cooper MD. Functional analysis of two human T-cell subpopulations: help and suppression of $\mathrm{B}$ cell responses by $T$ cells bearing receptors for $\operatorname{IgM}(\mathrm{T} \mu)$ or IgG (Ty). J Exp Med 1977; 146: 184-200.

21 Reinherz EL, Moretta L, Roper M et al. Human T lymphocyte subpopulations as defined by Fc receptors and monoclonal antibodies. A comparison. J Exp Med 1980; 151: 969-74.

22 Reinherz EL, Schlossman SF. The differentiation and function of human T lymphocytes. Cell 1980; 19: 821-7.

23 Truelove SC, Witts LJ. Cortisone in ulcerative colitis. Final report on a therapeutic trial. $\mathrm{Br} \mathrm{Med} J$ 1955; 2: 1041-8.

24 DeDombal FT, Burton IL, Clamp SE, Goligher JC. Short-term course and prognosis in Crohn's disease. Gut 1974; 15: 435-43.

25 Selby WS, Janossy G, Jewell DP. Immunohistological characterisation of intraepithelial lymphocytes of the human gastrointestinal tract. Gut 1981; 22: 169-76.

26 Yu DTY, Winchester RJ, Fu SM, Gibofsky A, Ko HS, Kunkel HG. Peripheral blood Ia-positive $\mathrm{T}$ cells. Increases in certain diseases and after immunization. J Exp Med 1980; 151: 91-100.
27 Evans RL, Faldetta TJ, Humphreys RE, Pratt DM, Yunis EJ, Schlossman SF. Peripheral human T cells sensitized in mixed leucocyte culture synthesize and express Ia-like antigens. $J$ Exp Med 1978; 148: 1440-5.

28 Boyum A. Isolation of leucocytes from human blood. Scand J Clin Invest 1968; 21 suppl 97: 77-89.

29 McMichael AJ, Pilch JR, Galfre G, Mason DY, Fabre JW, Milstein C. A human thymocyte antigen defined by a hybrid myeloma monoclonal antibody. Eur $J$ Immunol 1979; 9: 205-10.

30 Steel CM, Evans J, Smith MA. The sheep-cell rosette test on human peripheral blood lymphocytes: an analysis of some variable factors in the technique. $\mathrm{Br} \mathrm{J}$ Haematol 1974; 28: 245-51.

31 Asquith P, Kraft SC, Rothberg RM. Lymphocyte responses to nonspecific mitogens in inflammatory bowel disease. Gastroenterology 1973; 65: 1-7.

32 Bolton PM, James SL, Newcombe RG, Whitehead RH, Hughes LE. The immune competence of patients with inflammatory bowel disease. Gut 1974; 15: 213-9.

33 Raeman F, Decock W, DeBeukelaar T, Decree J, Verhaegen $H$. Enumeration of $T$ lymphocytes and $T$ lymphocyte subsets in autoimmune disease using monoclonal antibodies. Clin Exp Immunol 1981; 45: 475-9.

34 Bach MA, Bach JF. The use of monoclonal anti-T cell antibodies to study $T$ cell imbalances in human diseases. Clin Exp Immunol 1981; 45: 449-56.

35 Fiocchi C, Battisto JR, Farmer RG. Studies on isolated gut mucosal lymphocytes in inflammatory bowel disease. Detection of activated $T$ cells and enhanced proliferation to staphylococcus aureus and lipopolysaccharides. Dig Dis Sci 1981; 26: 728-36.

36 Hunninghake GW, Crystal RG. Pulmonary sarcoidosis. A disorder mediated by excess helper $\mathrm{T}$ lymphocyte activity at sites of disease activity. $N$ Engl J Med 1981; 305: 429-34.

37 Janossy G, Panayi G, Duke O, Bofill M, Poulter LW, Goldstein G. Rheumatoid arthritis: a disease of $T$ lymphocyte/macrophage immunoregulation. Lancet 1981; 2: 839-42.

38 Strickland RG, Husby G, Black WC, Williams RC. Peripheral blood and intestinal lymphocyte subpopulations in Crohn's disease. Gut 1975; 16: 847-53.

39 Meuwissen SGM, Feltkamp-Vroom TM, Brutel de la Riviere A, Von Dem Borne AEG, Tytgat GN. Analysis of the lymphoplasmacytic infiltrate in Crohn's disease with special reference to identification of lymphocyte-subpopulations. Gut 1976; 17: 770-80. 